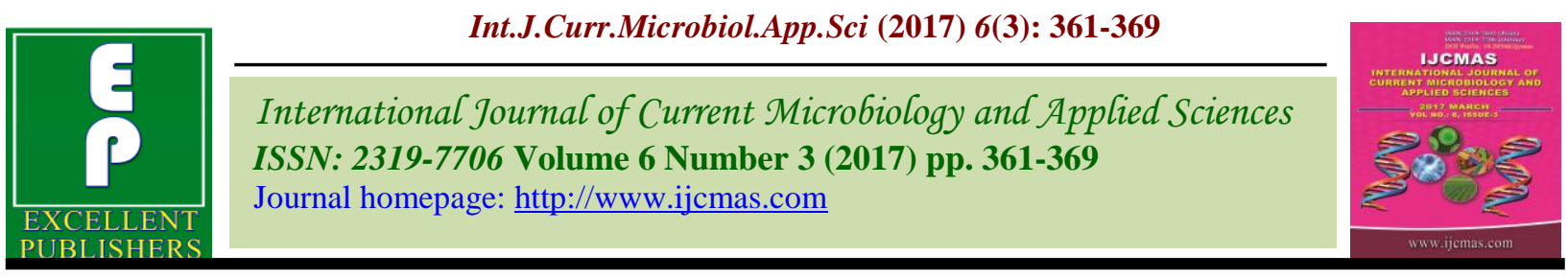

Original Research Article

https://doi.org/10.20546/ijcmas.2017.603.041

\title{
Morphological Characterization and Assessment of Genetic Variability in Soybean Varieties
}

\author{
Bhakuni Vandana $^{1}$, P.S. Shukla ${ }^{1}$, Singh Kamendra ${ }^{1}$ and Vikash Kumar Singh ${ }^{2}$ \\ ${ }^{1}$ Department of Genetics and Plant Breeding, College of Agriculture, \\ GBPUA\&T, Pantnagar, India \\ ${ }^{2}$ Department of Plant Pathology, Sam Higginbottom Institute of Agriculture and Technology \\ and Sciences, Allahabad - 211007, (UP), India \\ *Corresponding author
}

\section{A B S T R A C T}

\begin{tabular}{|l|}
\hline Ke y w o r d s \\
Genetic variability, \\
Heritability, Genetic \\
advance, Genotypic \\
coefficient of \\
variation, Phenotypic \\
coefficient of \\
variation, Soybean.
\end{tabular}

Twelve varieties of soybean (Glycine $\max$ (L.) Merrill.) were evaluated in randomized block design with three replications for variability, heritability and genetic advance during kharif 2013 and 2014. Observations on ten agronomic along with five morphological characters were observed. Analysis of variance revealed highly significant differences among the genotypes for the all the characters. High PCV coupled with high GCV, observed for number of primary branches per plant, number of nodes per plant, plant height and seed yield per plant. High heritability coupled with high genetic advance as percent of mean was observed for plant height, number of primary branches plant per plant and harvest index in both the years indicating operation of additive gene action and the ample scope for improvement in these traits through simple selection.

\section{Introduction}

Soybean [Glycine max (L.) Merrill] is a major oil seed crop in the world and is called as a golden bean or miracle bean because of its versatile nutritional qualities having $20 \%$ oil and 38 to 43 percent protein, which has biological value as meat and fish protein and rich in amino acids like lysine and tryptophan (Quayam et al., 1985). The assessment of available genetic variability is of utmost importance in all the crop improvement programmes. This is important for several reasons: the ability to distinguish reliably different genotypes is important for designing the breeding programmes, population-genetic analysis, genetic engineering and an estimation of the amount of variation within genotypes and between genotypes is useful for predicting potential genetic gains in a breeding programme and in setting up appropriate cross-breeding strategies. Genetic variability is the basic requirement for crop improvement as this provides wider scope for selection. Thus, effectiveness of selection is dependent upon the nature, extent and magnitude of genetic variability present in material and extent to which it is heritable. Hence, in present investigation was carried out to assess the variability of seed yield and 
yield contributing traits, along with indices of variability i.e., genotypic coefficient of variation (GCV), phenotypic coefficient of variation (PCV), heritability in broad sense $\left(\mathrm{h}^{2}\right)$, genetic advance (GA) and genetic advance as percent of mean (GA\%). This study will facilitate an understanding behind expression of character and also role of environment there in.

\section{Materials and Methods}

The experimental material consisted of 12 varieties of soybean derived from different origins. These varieties of soybean were evaluated in randomized block design with three replications during kharif 2013 and 2014 at N. E. Borlaug Crop Research Centre, G. B. Pant University of Agriculture and Technology, Pantnagar, Udham Singh Nagar, Uttarakhand. Each variety was accommodated in four rows of 4 meter in each replication, with a row to row distance of $45 \mathrm{~cm}$ and plant to plant distance was maintained at 5 to $7 \mathrm{~cm}$ after thinning. Same pattern was followed in kharif 2014. Observations on ten characters were recorded on randomly selected five plants from each genotype and average value was used for statistical analysis. The data is subjected to different statistical analysis viz., analysis of variance, magnitude of genetic variability were performed following standard procedures (Burton, 1952 and Allard, 1960).

\section{Results and Discussion}

\section{Morphological characterization}

All the twelve varieties were categorized on the basis of morphological characters. Varieties were thus categorized into five groups on the basis of five morphological characters i.e., presence or absence of pubescence, pubescence colour, flower, seed coat and hilum colour. On the basis of pubescence all varieties were categorized into two groups i.e., presence or absence of pubescence. All the varieties except JS 335 have pubescence. Hence, all the varieties except JS 335 fall into the category of pubescence. On the basis of pubescence colour varieties were divided into two groups namely, tawny and grey. Ankur, PS 1092, Kalitur, PS 1347, PS 1024, Bhatt, Bragg and PS 1029 were categorized into tawny group whereas PS 1225, PK 472, JS 335 and PK 327 were in the group of grey. Varieties were also categorized into two groups on the basis of their flower colour. Seven varieties namely, Ankur, PS 1225, PK 472, PS 1347, PS 1024, Bragg and PS 1029 belonged to the white flower group whereas PS 1092, Kalitur, JS 335, PK 327 and Bhatt were in the purple flower group. On the basis of seed coat colour varieties were divided into two groups namely, yellow and black. Kalitur and Bhatt belonged to the black seed coat colour group while all the remaining ten varieties belonged to the yellow seed coat colour group. Varieties were divided into three groups on the basis of hilum colour. PK 472 belonged to the light brown hilum colour group. PS 1225, PK 472, PS 1347, PS 1024 and PK 327 belonged to the brown group whereas PS 1092, Kalitur, JS 335, Bhatt, Bragg and PS 1029 belonged to the black hilum colour group (Table 1).

The results from the analysis of variance based on the observations recorded for 12 genotypes showed that the significant amount of variability was present in the experimental material for all the characters studied in kharif 2013 and 2014.

\section{Genotypic Coefficient of Variation (GCV) and Phenotypic Coefficient of variation (PCV)}

Effective selection depends on the existence of the genetic variability. Phenotypic coefficient of variation (PCV) and genotypic 
coefficient of variation (GCV) for the various traits were also observed during the study. These results indicated that variability was primarily due to genotypic differences. Therefore, selection based on these characters is expected to be effective.

The present study revealed adequate variation in almost all characters under study in the year 2013 as well as 2014. The phenotypic, genotypic and environmental coefficient of variation, heritability (\%), expected genetic advance and genetic advance as per cent of mean are presented in table 3 . In both the years i.e., 2013 and 2014, estimated values of phenotypic coefficient of variation were higher than genotypic coefficient of variation for all the characters studied. In the year 2013, plant height exhibited highest phenotypic coefficient of variation $(25.06 \%)$ followed by yield per plant $(22.78 \%)$, number of primary branches per plant $(19.50 \%)$, dry matter weight per plant $(17.56 \%)$ and number of nodes per plant (17.33\%). The lowest phenotypic coefficient of variation was observed for days to maturity (3.94\%). Similar result was obtained for genotypic coefficient of variation. In the year 2014 highest phenotypic coefficient of variation was recorded for plant height $(26.13 \%)$ followed yield per plant $(21.97 \%)$, number of nodes per plant $(21.57 \%)$, number of primary branches per plant (21.38), dry matter weight per plant $(17.06 \%)$, number of pods per plant $(14.11 \%)$, days to $50 \%$ flowering $(10.69 \%)$, harvest index $(9.32 \%)$, number of seeds per pod $(7.55 \%)$ and days to maturity (3.65\%). Range of genotypic coefficient of variation was observed from $3.57 \%$ (days to maturity) to $25.94 \%$ (plant height). In 2013, environmental coefficient of variation ranged from $0.79 \%$ (days to maturity) to $8.38 \%$ (number of seeds per pod). Highest environmental coefficient of variation was noticed for number of seeds per pod (8.38) followed by seed yield per plant (7.81) and number of nodes per plant $(6.72 \%)$ while the lowest value was recorded for days to maturity $(0.79 \%)$. In 2014 also, environmental coefficient of variation ranged from $0.76 \%$ (days to maturity) to $9.04 \%$ (number of nodes per plant). Similar findings have been reported by Puspendra and Ram (1987), Sudaric et al., (2009), Pandey et al., (2008) and Bekele et al., (2012).

\section{Heritability and genetic advance}

The heritability refers to as an index of transmissibility, to measure the genetic relationship between the parents and their offspring's. Heritability infers as to how much emphasis should be placed for selection in case of a particular trait. Heritability estimates and genetic advance are the important genetic parameters. The knowledge of heritability coupled with expected genetic advance for a trait will help in deciding the scope of improvement of that particular trait through selection (Johnson et al., 1955).

Most of the traits included in this investigation were considered highly heritable as they have shown to be associated with moderate to high estimate of broad sense heritability. In the year 2013 highest heritability in broad sense was obtained for plant height $(97 \%)$ followed by days to maturity $(95 \%)$, number of primary branches per plant $(94 \%)$, days to $50 \%$ flowering (93\%), dry matter weight per plant (89\%), number of pods per plant $(89 \%)$, yield per plant $(88 \%)$, harvest index $(82 \%)$ and number of nodes per plant (84\%). Heritability estimates in broad sense were low for number of seeds per pod (48\%). Similarly in 2014 high, moderate and low broad sense heritability was obtained, in which highest value of heritability was found for plant height $(98 \%)$ followed by number of primary branches per plant (97\%), days to $50 \%$ flowering (97\%), days to maturity (95\%), 
number of pods per plant (93\%), yield per plant $(85 \%)$, dry matter weight per plant $(84 \%)$, harvest index $(83 \%)$ and number of nodes per plant $(82 \%)$. The lowest heritability was recorded for number of seeds per pod (26\%). High heritability estimates for different characters were also reported Puspendra and Ram (1987), Sudaric et al., (2009), Pandey et al., (2008) and Bekele et al., (2012).

Table.1 Morphological characterization of soybean varieties

\begin{tabular}{|c|c|c|c|c|c|c|}
\hline Sl. No. & Variety & Pubescence & $\begin{array}{c}\text { Pubescence } \\
\text { colour }\end{array}$ & $\begin{array}{c}\text { Flower } \\
\text { colour }\end{array}$ & $\begin{array}{c}\text { Seed coat } \\
\text { colour }\end{array}$ & $\begin{array}{c}\text { Hilum } \\
\text { colour }\end{array}$ \\
\hline $\mathbf{1 .}$ & Ankur & Present & Tawny & White & Yellow & Brown \\
\hline $\mathbf{2 .}$ & PS 1225 & Present & Grey & White & Yellow & Brown \\
\hline $\mathbf{3 .}$ & PK 472 & Present & Grey & White & Yellow & Light Brown \\
\hline $\mathbf{4 .}$ & PS 1092 & Present & Tawny & Purple & Yellow & Black \\
\hline $\mathbf{5 .}$ & Kalitur & Present & Tawny & Purple & Black & Black \\
\hline $\mathbf{6 .}$ & JS 335 & Absent & Glabrous & Purple & Yellow & Black \\
\hline $\mathbf{7 .}$ & PS 1347 & Present & Tawny & White & Yellow & Brown \\
\hline $\mathbf{8 .}$ & PS 1024 & Present & Tawny & White & Yellow & Brown \\
\hline $\mathbf{9 .}$ & PK 327 & Present & Grey & Purple & Yellow & Brown \\
\hline $\mathbf{1 0 .}$ & Bhatt & Present & Tawny & Purple & Black & Black \\
\hline $\mathbf{1 1 .}$ & Bragg & Present & Tawny & White & Yellow & Black \\
\hline $\mathbf{1 2 .}$ & PS 1029 & Present & Twny & White & Yellow & Black \\
\hline
\end{tabular}

Table.2 Analysis of variance for yield and other characters of soybean varieties in kharif 2013 and 2014

\begin{tabular}{|c|c|c|c|c|c|c|c|c|c|c|c|c|}
\hline \multirow[t]{2}{*}{$\begin{array}{l}\text { Source of } \\
\text { Variation }\end{array}$} & $\begin{array}{c}\text { Degree } \\
\text { of }\end{array}$ & \multicolumn{11}{|c|}{ Mean Sum of Squares } \\
\hline & & Year & $\begin{array}{c}\text { Days to } \\
50 \% \\
\text { flowering }\end{array}$ & $\begin{array}{c}\text { Days to } \\
\text { maturity }\end{array}$ & $\begin{array}{c}\text { Plant height } \\
\text { (cm) }\end{array}$ & $\begin{array}{l}\text { Number } \\
\text { of nodes } \\
\text { per plant }\end{array}$ & $\begin{array}{c}\text { Number } \\
\text { of } \\
\text { primary } \\
\text { branches } \\
\text { per plant }\end{array}$ & $\begin{array}{c}\text { Number } \\
\text { of pods } \\
\text { per plant }\end{array}$ & $\begin{array}{l}\text { Number } \\
\text { of seeds } \\
\text { per pod }\end{array}$ & $\begin{array}{c}\text { Dry } \\
\text { matter } \\
\text { weight } \\
\text { per } \\
\text { plant(g) }\end{array}$ & $\begin{array}{c}\text { Harvest } \\
\text { index }(\%)\end{array}$ & $\begin{array}{c}\text { Seed } \\
\text { yield per } \\
\text { plant (g) }\end{array}$ \\
\hline \multirow{2}{*}{ Replication } & \multirow{2}{*}{2} & 2013 & 4.361 & 7.00 & 3.968 & 1.714 & 0.052 & 29.705 & 0.147 & 16.532 & 2.870 & 0.541 \\
\hline & & 2014 & 2.083 & 3.031 & 14.721 & 7.940 & 0.028 & 24.46 & 0.0019 & 0.324 & 4.167 & 0.823 \\
\hline \multirow{2}{*}{ Treatment } & \multirow{2}{*}{11} & 2013 & $86.080 * *$ & $67.098 * *$ & $928.094 * *$ & $22.526 * *$ & $2.102 * *$ & $324.289 * *$ & $0.144 * *$ & $214.224 * *$ & $\mid 56.328 * *$ & $29.529 * *$ \\
\hline & & 2014 & $86.553 * *$ & $57.543 * *$ & $1011.161 * *$ & $30.177 * *$ & $2.406^{* *}$ & $297.891 * *$ & $0.044 * *$ & $213.83 * *$ & $36.409 * *$ & $56.477 * *$ \\
\hline \multirow{2}{*}{ Error } & \multirow{2}{*}{22} & 2013 & 1.967 & 0.939 & 8.013 & 1.256 & 0.037 & 12.756 & 0.038 & 7.715 & 1.918 & 2.399 \\
\hline & & 2014 & 0.659 & 0.875 & 5.085 & 2.004 & 0.020 & 6.392 & 0.021 & 12.526 & 2.196 & 3.041 \\
\hline
\end{tabular}

**Significant at $1 \%$ level of probability 
Table.3 General Mean (GM), Range, Standard Error of Mean (SEm) and variability parameters of soybean varieties in kharif 2013 and 2014

\begin{tabular}{|c|c|c|c|c|c|c|c|c|c|c|}
\hline Character & Year & GM & Range & $\begin{array}{l}\text { SEm } \\
\pm\end{array}$ & PCV & GCV & $\mathbf{E C V}$ & $\mathbf{h}^{2}$ & GA & $\begin{array}{r}\text { GA } \\
(\%)\end{array}$ \\
\hline \multirow{2}{*}{ Days to $50 \%$ flowering } & 2013 & 50.44 & $43.33-59$ & 0.80 & 10.85 & 10.49 & 2.78 & 0.93 & 10.54 & 20.90 \\
\hline & 2014 & 52.58 & $45-61$ & 0.46 & 10.69 & 10.57 & 1.60 & 0.97 & 10.89 & 20.71 \\
\hline \multirow{2}{*}{ Days to maturity } & 2013 & 121.58 & 112.66-131 & 0.55 & 3.94 & 3.86 & 0.79 & 0.95 & 9.47 & 7.79 \\
\hline & 2014 & 124.64 & $116-134$ & 0.54 & 3.65 & 3.57 & 0.76 & 0.95 & 8.75 & 7.19 \\
\hline \multirow{2}{*}{ Plant height (cm) } & 2013 & 70.76 & $52.26-115.20$ & 1.63 & 25.06 & 24.74 & 4.00 & 0.97 & 35.61 & 50.33 \\
\hline & 2014 & 70.58 & $53.06-116.33$ & 1.13 & 26.13 & 25.94 & 3.19 & 0.98 & 37.44 & 53.05 \\
\hline \multirow{2}{*}{ Number of nodes per plant } & 2013 & 16.66 & $14.13-23.35$ & 0.64 & 17.33 & 15.97 & 6.72 & 0.84 & 5.05 & 30.31 \\
\hline & 2014 & 15.64 & $12.66-23.13$ & 0.81 & 21.57 & 19.58 & 9.04 & 0.82 & 5.73 & 36.64 \\
\hline \multirow{2}{*}{$\begin{array}{c}\text { Nụmber of primary } \\
\text { branches } \\
\cdot \quad \text { per plant }\end{array}$} & 2013 & 4.36 & $3.46-6.13$ & 0.11 & 19.50 & 18.99 & 4.43 & 0.94 & 1.66 & 38.07 \\
\hline & 2014 & 4.22 & $3.27-6.28$ & 0.08 & 21.38 & 21.11 & 3.40 & 0.97 & 1.81 & 42.89 \\
\hline \multirow{2}{*}{ Number of pods per plant } & 2013 & 69.84 & $48.66-90$ & 2.06 & 15.46 & 14.59 & 5.11 & 0.89 & 19.81 & 28.36 \\
\hline & 2014 & 72.09 & $53.69-90.70$ & 1.14 & 14.11 & 13.67 & 3.50 & 0.93 & 19.66 & 27.27 \\
\hline \multirow{2}{*}{ Number of seeds per pod } & 2013 & 2.35 & $2.04-2.72$ & 0.11 & 11.63 & 8.06 & 8.38 & 0.48 & 0.26 & 11.06 \\
\hline & 2014 & 2.25 & $2.1-2.52$ & 0.08 & 7.55 & 3.88 & 6.47 & 0.26 & 0.09 & 4.00 \\
\hline \multirow{2}{*}{$\begin{array}{c}\text { Dry matter weight per plant } \\
(\text { g) }\end{array}$} & 2013 & 49.81 & $34-60.67$ & 1.60 & 17.56 & 16.65 & 5.57 & 0.89 & 16.20 & 32.52 \\
\hline & 2014 & 52.30 & $35.11-61.10$ & 2.04 & 17.06 & 15.66 & 6.76 & 0.84 & 15.49 & 29.62 \\
\hline \multirow{2}{*}{ Harvest index (\%) } & 2013 & 39.58 & $30.31-44.01$ & 0.79 & 8.43 & 7.67 & 3.50 & 0.82 & 5.68 & 14.35 \\
\hline & 2014 & 39.91 & $32.68-45.1$ & 0.85 & 9.32 & 8.53 & 3.74 & 0.83 & 6.37 & 15.96 \\
\hline \multirow{2}{*}{ Seed yield per plant (g) } & 2013 & 19.81 & $12.47-26.70$ & 0.89 & 22.78 & 21.40 & 7.81 & 0.88 & 8.20 & 41.39 \\
\hline & 2014 & 20.91 & $13.27-27.03$ & 1.00 & 21.97 & 20.30 & 8.39 & 0.85 & 8.03 & 38.40 \\
\hline
\end{tabular}

Whereas, GM= General Mean, SEm $\pm=$ Standard Error of Mean, PCV=Phenotypic Coefficient of Variation, GCV= Genotypic Coefficient of Variation, $E C V=$ Environmental Coefficient of Variation, $h^{2}=$ Heritability, $G_{A}=$ Genetic advance $(5 \%)$ and $\mathrm{G}_{\mathrm{A}}(\%)=$ Genetic advance as $\%$ of mean 
Table.4 Mean performance of yield and other characters of soybean varieties in kharif 2013

\begin{tabular}{|c|c|c|c|c|c|c|c|c|c|c|c|}
\hline $\begin{array}{l}\text { S. } \\
\text { No. }\end{array}$ & Varieties & $\begin{array}{c}\text { Days to } \\
50 \% \\
\text { flowering }\end{array}$ & $\begin{array}{l}\text { Days to } \\
\text { maturity }\end{array}$ & $\begin{array}{c}\text { Plant } \\
\text { height }(\mathrm{cm})\end{array}$ & $\begin{array}{c}\text { Number of } \\
\text { nodes per } \\
\text { plant }\end{array}$ & $\begin{array}{c}\text { Number of } \\
\text { primary } \\
\text { branches } \\
\text { per plant }\end{array}$ & $\begin{array}{c}\text { Number } \\
\text { of pods } \\
\text { per plant }\end{array}$ & $\begin{array}{l}\text { Number } \\
\text { of seeds } \\
\text { per pod }\end{array}$ & $\begin{array}{c}\text { Dry matter } \\
\text { weight per } \\
\text { plant }(g)\end{array}$ & $\begin{array}{c}\text { Harvest } \\
\text { index }(\%)\end{array}$ & $\begin{array}{c}\text { Seed yield } \\
\text { per plant (g) }\end{array}$ \\
\hline 1. & Ankur & 59.00 & 131.00 & 63.66 & 16.80 & 3.67 & 74.33 & 2.04 & 34.00 & 36.65 & 12.47 \\
\hline 2. & PS 1225 & 54.00 & 122.00 & 70.10 & 16.00 & 4.80 & 90.00 & 2.17 & 60.67 & 44.01 & 26.70 \\
\hline 3. & PK 472 & 50.33 & 120.66 & 52.26 & 15.46 & 4.59 & 70.40 & 2.32 & 58.66 & 39.37 & 23.11 \\
\hline 4. & PS 1092 & 51.33 & 116.00 & 61.93 & 14.40 & 4.60 & 73.99 & 2.33 & 54.53 & 41.79 & 22.82 \\
\hline 5. & Kalitur & 58.33 & 126.00 & 96.86 & 20.60 & 5.13 & 48.66 & 2.52 & 45.76 & 37.01 & 16.91 \\
\hline 6. & JS 335 & 43.66 & 120.33 & 69.86 & 17.60 & 3.59 & 73.31 & 2.32 & 56.13 & 39.81 & 22.36 \\
\hline 7. & PS 1347 & 53.00 & 123.00 & 62.03 & 16.13 & 3.50 & 78.62 & 2.51 & 59.72 & 42.85 & 25.60 \\
\hline 8. & PS 1024 & 46.00 & 118.33 & 66.20 & 16.00 & 4.65 & 66.40 & 2.72 & 44.43 & 40.85 & 18.15 \\
\hline 9. & PK 327 & 43.33 & 112.66 & 59.70 & 14.13 & 4.80 & 62.87 & 2.28 & 43.53 & 43.08 & 18.77 \\
\hline 10. & Bhatt & 53.33 & 125.00 & 115.20 & 23.35 & 6.13 & 59.53 & 2.40 & 47.88 & 30.31 & 14.51 \\
\hline 11. & Bragg & 45.00 & 122.00 & 64.26 & 14.46 & 3.46 & 74.50 & 2.42 & 51.86 & 37.12 & 19.24 \\
\hline 12. & PS 1029 & 48.00 & 122.00 & 67.06 & 15.06 & 3.47 & 65.46 & 2.24 & 40.53 & 42.19 & 17.10 \\
\hline & Mean & 50.44 & 121.58 & 70.76 & 16.66 & 4.36 & 69.84 & 2.35 & 49.81 & 39.58 & 19.81 \\
\hline & S.Em. \pm & 0.80 & 0.55 & 1.63 & 0.64 & 0.11 & 2.06 & 0.11 & 1.60 & 0.79 & 0.89 \\
\hline & C. D. $5 \%$ & 2.37 & 1.64 & 4.79 & 1.89 & 0.32 & 6.04 & 0.33 & 4.70 & 2.34 & 2.62 \\
\hline & C. D. $1 \%$ & 3.22 & 2.23 & 6.51 & 2.57 & 0.44 & 8.21 & 0.44 & 6.39 & 3.18 & 3.56 \\
\hline & C. V $(\%)$ & 2.78 & 0.79 & 4.00 & 6.72 & 4.43 & 5.11 & 8.38 & 5.57 & 3.50 & 7.81 \\
\hline
\end{tabular}


Table.5 Mean performance of yield and other characters of soybean varieties in kharif 2014

\begin{tabular}{|c|c|c|c|c|c|c|c|c|c|c|c|}
\hline S. No & Variety & $\begin{array}{c}\text { Days to } \\
50 \% \\
\text { flowering }\end{array}$ & $\begin{array}{c}\text { Days to } \\
\text { maturity }\end{array}$ & $\begin{array}{c}\text { Plant } \\
\text { height }(\mathrm{cm})\end{array}$ & $\begin{array}{c}\text { Number of } \\
\text { nodes per } \\
\text { plant }\end{array}$ & $\begin{array}{c}\text { Number of } \\
\text { primary } \\
\text { branches per } \\
\text { plant }\end{array}$ & $\begin{array}{c}\text { Number } \\
\text { of pods } \\
\text { per plant }\end{array}$ & $\begin{array}{l}\text { Number } \\
\text { of seeds } \\
\text { per pod }\end{array}$ & $\begin{array}{c}\text { Dry matter } \\
\text { Weight per } \\
\text { plant }(g)\end{array}$ & $\begin{array}{c}\text { Harvest } \\
\text { index (\%) }\end{array}$ & $\begin{array}{c}\text { Seed yield } \\
\text { per plant }(\mathrm{g})\end{array}$ \\
\hline 1. & Ankur & 60.00 & 134.00 & 58.90 & 13.46 & 3.80 & 74.06 & 2.10 & 35.11 & 37.82 & 13.27 \\
\hline 2. & PS 1225 & 55.67 & 124.67 & 65.66 & 15.66 & 4.60 & 90.70 & 2.13 & 59.93 & 45.10 & 27.03 \\
\hline 3. & PK 472 & 53.00 & 124.00 & 53.06 & 16.13 & 4.76 & 71.13 & 2.26 & 57.83 & 40.35 & 23.37 \\
\hline 4. & PS 1092 & 55.00 & 120.33 & 60.53 & 12.66 & 4.40 & 81.32 & 2.20 & 61.10 & 41.32 & 25.28 \\
\hline 5. & Kalitur & 61.00 & 128.67 & 99.83 & 20.40 & 3.27 & 53.69 & 2.12 & 50.16 & 35.35 & 17.74 \\
\hline 6. & JS 335 & 45.00 & 124.00 & 69.46 & 16.80 & 3.53 & 76.53 & 2.37 & 57.00 & 41.41 & 23.56 \\
\hline 7. & PS 1347 & 56.00 & 126.00 & 65.26 & 14.60 & 3.65 & 80.59 & 2.52 & 61.00 & 42.57 & 25.95 \\
\hline 8. & PS 1024 & 47.33 & 122.33 & 67.40 & 13.66 & 4.80 & 67.90 & 2.25 & 46.39 & 41.40 & 19.21 \\
\hline 9. & PK 327 & 48.00 & 116.00 & 62.46 & 13.66 & 4.87 & 64.93 & 2.22 & 46.00 & 42.80 & 19.68 \\
\hline 10. & Bhatt & 54.67 & 127.00 & 116.33 & 23.13 & 6.28 & 61.29 & 2.31 & 50.00 & 32.68 & 16.32 \\
\hline 11. & Bragg & 46.00 & 124.67 & 64.06 & 14.40 & 3.33 & 75.89 & 2.34 & 59.86 & 35.33 & 21.16 \\
\hline \multirow[t]{6}{*}{12.} & PS 1029 & 49.33 & 124.00 & 64.06 & 13.13 & 3.40 & 67.06 & 2.18 & 43.19 & 42.79 & 18.43 \\
\hline & Mean & 52.58 & 124.64 & 70.58 & 15.64 & 4.22 & 72.09 & 2.25 & 52.30 & 39.91 & 20.91 \\
\hline & $\begin{array}{c}\text { S.Em. } \\
\pm\end{array}$ & 0.46 & 0.54 & 1.30 & 0.81 & 0.83 & 1.45 & 0.08 & 2.04 & 0.85 & 1.01 \\
\hline & $\begin{array}{l}\text { C. D. } \\
5 \%\end{array}$ & 1.37 & 1.58 & 3.81 & 2.39 & 0.24 & 4.28 & 0.24 & 5.99 & 2.50 & 2.95 \\
\hline & $\begin{array}{l}\text { C. D. } \\
1 \%\end{array}$ & 1.86 & 2.15 & 5.19 & 3.25 & 0.33 & 5.81 & 0.33 & 8.14 & 3.41 & 4.01 \\
\hline & $\begin{array}{l}\text { C. V } \\
(\%)\end{array}$ & 1.60 & 0.76 & 3.19 & 9.04 & 3.40 & 3.50 & 6.47 & 6.76 & 3.74 & 8.39 \\
\hline
\end{tabular}

High heritability for the traits of economic importance viz., plant height and number of pods per plant indicated that the direct selection would be effective for improvement of these characters.

Expected genetic advance indicates the expected genetic progress for a particular trait under a selection cycle and measures the extent of its stability under selection pressure. In the present investigation expected genetic advance varied from $0.26 \%$ for number of seeds per pod to $35.61 \%$ for plant height. Besides plant height, number of pods per plant $(19.81 \%)$ and dry matter weight per plant $(16.20 \%)$ exhibited high genetic advance in 2013 whereas, in the year 2014 expected genetic advance varied from $0.09 \%$ (number of seeds per pod) to $37.44 \%$ (plant height). Highest value of expected genetic advance showed by plant height (37.44\%) was followed by number of pods per plant 
$(19.66 \%)$ and dry matter weight per plant $(15.49 \%)$

In 2013 genetic advance as per cent of mean exhibited highest value for plant height $(50.33 \%)$ followed by yield per plant (41.39\%), number of primary branches per plant $(38.07 \%)$, dry matter weight per plant $(32.52 \%)$ and number of nodes per plant $(30.31 \%)$. Days to maturity showed the lowest value $(7.79 \%)$ for genetic advance as per cent of mean. In 2014 high estimates of genetic advance expressed as per cent of mean was observed for plant height $(53.05 \%)$ followed by number of primary branches per plant (42.89\%), yield per plant $(38.40 \%)$, number of nodes per plant (36.64\%), dry matter weight per plant $(29.62 \%)$ and number of pods per plant (27.27\%). Low estimates of genetic advance as per cent of mean were observed for number of seeds per pod (4.00\%).

High estimates of heritability does not always mean high genetic advance. Thorat et al., (1999) suggested that heritability estimates and the genetic advance as per cent of mean together would provide a better judgment rather than heritability alone in predicting the resultant effect of selection. High heritability coupled with high genetic advance was observed for number of pods per plant and harvest index in both the years. The results suggest that there is a wide scope for improvement of this trait through simple selection procedure (Ramana, 2003; Kausar, 2006). Characters with high heritability and high genetic advance indicate that these characters are governed by additive gene effect and direct selection can bring the desired improvement in such traits. High heritability coupled with high genetic advance as percent of mean was recorded indicates the predominance of additive gene action in the expression of Plant height (Kausar, 2006; Sriranjani, 2007). High estimates coupled with high genetic advance for number of pods per plant were also reported by Malik and Singh (1987).

High heritability for all the characters and high genetic advance for plant height, number of pods per plant and dry matter weight per plant was also reported by Praveenkumar (2005). High heritability coupled with high genetic advance as percent of mean for plant height, number of primary branches per plant and seed yield per plant indicates the operation of additive genes and offer the best possibility for improvement of this trait through mass selection, progeny selection, family selection to any other suitable modified selection procedure aiming to exploit the additive gene effects (Kausar, 2006).

The results suggest that there is a wide scope for improvement of this trait through simple selection procedure (Sriranjani, 2007). Thus, from the present investigation, it can be concluded that high genetic advance was not always associated with high heritability for the characters studied (Tables 2-5).

In conclusion, the analysis of variance showed significant difference among the varieties of all characters studied indicating that the data generated from the above diverse material shall represent wide variability. The genotypic coefficient of variation for all characters studied was lesser than the phenotypic coefficient of variation. High PCV coupled with high GCV, observed for number of primary branches per plant, number of nodes per plant, plant height and seed yield per plant indicating the presence of wider variability for these traits in the varieties studied. High heritability coupled with high genetic advance as percent of mean was observed for plant height, number of primary branches per plant and seed yield per plant indicates the operation of additive gene action 
in the inheritance of these traits and improvement in these characters is possible through simple selection.

\section{References}

Allard, R.W. 1960. Principles of plant breeding, John Wiley and Sons, New York

Bekele, A., Getint, A. and Habtamu, Z. 2012. Genetic divergence among soybean (Glycine $\max \quad$ (L) Merrill) introductions in Ethiopia based on agronomic traits. J. Biol. Agri. Healthcare, 2(6): 6-12.

Burton, G.W. 1952. Quantitative inheritance in grasses. proc. sixth international Grassland Congress. Pennsyvania State College, PA, US, 1:24.

Hina Kausar. 2006. Genetic investigations in segregating populations of soybean [Glycine max (L.) Merrill]. Karnataka J. Agri. Sci., 19(1): 200.

Johnson, H.W., Robinson, H.F. and Comstock, R.E. 1955. Estimates of genetic and environmental variability in soybean. Agron. J., 47: 314-318.

Malik, S.S. and Singh, B.B. 1987. Genetic variability and heritability in interspecific crosses of soybean.

Pandey, K., Singh, K., Singh, B.V., Pushpendra; Gupta, M.K. and Yadav, N.S. 2008. Character association and path coefficient analysis in advance breeding lines of soybean [Glycine max (L.) Merrill.]. Soybean Res., 45: 34-38.

Praveenkumar, A., Ramana, M.V., Razia
Sultana and Srinivasa Rao, V. 2005. Character association and path Analysis in soybean [Glycine max (L.) Merrill] during non-conventional rabi season. Andhra Agri. J., 52: 4851.

Pushpendra and Ram, H.H. 1987. Genetic components of variation for certain yield contributing traits in soybean. Indian J. Agric. Sci., 57(4): 221-224.

Quayam, A., Rao, M.S.S. and Violet Kerketta. 1985. Soybean: A miracle oil seed crop-its prospects and constraints in Bihar plateau. In proceedings of Oil Seed Production Constraints and Opportunities, pp: 219-232.

Ramana, M.V. 2003. Genetic studies on soybean (Glycine max (L.) Merrill) in non-traditional areas and seasons. Ph.D Thesis ANGR Agricultural University, Hyderabad.

Sriranjani, K., Ramana, M.V., Srinivasa Roa, V. and Rama Kumar, P.V. 2007. Correlation and path analysis in soybean (Glycine max (L.) Merrill). The Andhra Agri. J., 54: 6-8.

Sudaric, A., Vrataric, M., Volenik, M., Matosa, M. and Duvnjak, V. 2009. Heterosis and heterobeltiosis for grain yield components in soybean. Acta Agronomica Sinica., 35(4): 620-630.

Thorat, A., Khorgade, P.W., Ghorade and Ghodke, M. 1999. Variability, heritability andGenetic advance in soybean [Glycine max (L.) Merrill]. J. Soils and Crops, 9: 198-200.

\section{How to cite this article:}

Bhakuni Vandana, P.S. Shukla, Singh Kamendra and Vikash Kumar Singh. 2017. Morphological Characterization and Assessment of Genetic Variability in Soybean Varieties. Int.J.Curr.Microbiol.App.Sci. 6(3): 361-369. doi: https://doi.org/10.20546/ijcmas.2017.603.041 